\title{
Arenicella xantha gen. nov., sp. nov., a gammaproteobacterium isolated from a marine sandy sediment
}

\author{
Lyudmila A. Romanenko, ${ }^{1}$ Naoto Tanaka, $^{2}$ Galina M. Frolova ${ }^{1}$ \\ and Valery V. Mikhailov ${ }^{1}$ \\ ${ }^{1}$ Pacific Institute of Bioorganic Chemistry, Far-Eastern Branch, Russian Academy of Sciences, \\ 690022 Vladivostok, Prospect 100 Let Vladivostoku, 159, Russia \\ ${ }^{2}$ NODAI Culture Collection Center, Tokyo University of Agriculture, 1-1-1 Sakuragaoka, Setagaya- \\ ku, Tokyo 156-8502, Japan
}

Correspondence

Lyudmila A. Romanenko Iro@piboc.dvo.ru

\begin{abstract}
A Gram-negative, aerobic, yellow-pigmented, rod-shaped, non-motile bacterium, strain KMM $3895^{\top}$, was isolated from a marine sandy sample collected offshore from the Sea of Japan. Phylogenetic analysis based on the $16 \mathrm{~S}$ rRNA gene sequence placed strain KMM $3895^{\top}$ in the class Gammaproteobacteria, forming a separate branch, sharing $89.5 \%$ sequence similarity with Nitrincola lacisaponensis $4 \mathrm{CA}^{\top}$ and $88-87 \%$ similarity with the other members of the cluster, including members of Kangiella, Spongiibacter, Alcanivorax and Microbulbifer. The major isoprenoid quinone was Q-8. Polar lipids consisted of phosphatidylethanolamine, phosphatidylglycerol, diphosphatidylglycerol, aminophospholipid and an unknown phospholipid. Fatty acid analysis revealed $\mathrm{C}_{16: 1} \omega 7$, iso- $\mathrm{C}_{16: 0}$, iso- $\mathrm{C}_{18: 0}$ and $\mathrm{C}_{18: 1} \omega 7$ as dominant components. The DNA G $+\mathrm{C}$ content was determined to be $48.1 \mathrm{~mol} \%$. Based on its unique phenotypic characteristics and phylogenetic distance, the marine coastal sediment isolate KMM $3895^{\top}$ should be classified as a representative of a novel genus and species, for which the name Arenicella xantha gen. nov., sp. nov. is proposed. The type strain of Arenicella xantha is KMM $3895^{\top}\left(=\right.$ NRIC $0759^{\top}={ }^{\top}$ CM $\left.16153^{\top}\right)$.
\end{abstract}

In the course of a survey of the biodiversity of microorganisms that are associated with coastal marine environments, a Gram-negative, aerobic, yellow-pigmented, nonmotile bacterium, strain $\mathrm{KMM} 3895^{\mathrm{T}}$, was isolated from a sandy sediment sample collected offshore on the coast of the Sea of Japan, Russia, and characterized by phenotypic and phylogenetic analyses.

Strain KMM $3895^{\mathrm{T}}$ was isolated from a sediment sample taken at a depth of $2 \mathrm{~m}$, as described previously (Romanenko et al., 2004). The bacterium was grown aerobically on marine 2216 agar (MA) or marine broth $(\mathrm{MB})$ at $25-28{ }^{\circ} \mathrm{C}$, and was stored at $-80{ }^{\circ} \mathrm{C}$ in liquid MB supplemented with $30 \%(\mathrm{v} / \mathrm{v})$ glycerol. Motility was observed by the hanging-drop method as described by Gerhardt et al. (1994). Gram staining, oxidase and catalase activities and hydrolytic reactions for gelatin, casein, chitin, starch, CM-cellulose, DNA and Tweens 20, 40 and 80 were tested according to the standard methods described by

The GenBank/EMBL/DDBJ accession number for the 16S rRNA gene sequence of strain KMM $3895^{\top}$ is AB500096.

Results of 2D TLC of polar lipids of strain KMM $3985^{\top}$ and a $16 \mathrm{~S}$ rRNA gene sequence-based maximum-parsimony tree are available as supplementary material with the online version of this paper.
Smibert \& Krieg (1994). Formation of $\mathrm{H}_{2} \mathrm{~S}$ from thiosulfate was tested using a lead acetate paper strip. Acid production from carbohydrates was examined using the oxidation/ fermentation medium of Leifson (1963) for marine bacteria. The ability of strain KMM $3895^{\mathrm{T}}$ to grow in the presence of organic substrates as sole carbon and energy sources was tested for 4 weeks on an artificial seawater (ASW)-based medium supplemented with $2 \mathrm{~g} \mathrm{NH}_{4} \mathrm{Cl}$ and 0.5 g yeast extract $1^{-1}$ and $0.4 \%$ carbon source. The ASW contained (per litre distilled water) $30 \mathrm{~g} \mathrm{NaCl}, 4.9 \mathrm{~g} \mathrm{MgCl}_{2}$, $3.9 \mathrm{~g} \mathrm{Na}_{2} \mathrm{SO}_{4}, 1.1 \mathrm{~g} \mathrm{CaCl}_{2}, 0.66 \mathrm{~g} \mathrm{KCl}, 0.2 \mathrm{~g} \mathrm{NaHCO}_{3}$, $0.096 \mathrm{~g} \mathrm{KBr}, 0.026 \mathrm{~g} \mathrm{H}_{3} \mathrm{BO}_{3}, 0.024 \mathrm{~g} \mathrm{SrCl}_{2}$ and $0.003 \mathrm{~g}$ $\mathrm{NaF}$. Requirements for organic growth factors and sodium ions were tested on the basal medium of Baumann \& Baumann (1981) supplemented with $0.1 \%$ glycerol, $0.1 \%$ potassium acetate or $0.1 \%$ potassium succinate, and on basal medium in which the $\mathrm{Na}^{+}$salts had been replaced by equimolar amounts of $\mathrm{K}^{+}$salts, respectively. Requirement for and tolerance of $\mathrm{NaCl}$ were tested on ASW-based medium using various concentrations of $\mathrm{NaCl}$ in the range 0-20\%, supplemented with $\left(1^{-1}\right) 10.0 \mathrm{~g}$ Bacto peptone, 2.0 g yeast extract, $0.028 \mathrm{~g} \mathrm{FeSO}_{4}$ and $15.0 \mathrm{~g}$ agar. Growth at different temperatures and $\mathrm{pH}$ and antibiotic resistance were studied as described previously (Romanenko et al., 
2004, 2005). In addition, biochemical tests were carried out using API 20 NE, API $20 \mathrm{E}$ and API ZYM test kits (bioMérieux) according to the manufacturer's instructions, except that the culture was suspended in ASW.

For polar lipid and fatty acid analyses, strain KMM $3895^{\mathrm{T}}$ was cultivated on $\mathrm{MA}$ at $28{ }^{\circ} \mathrm{C}$ for 3 days and lipids were extracted using the chloroform/methanol extraction method of Bligh \& Dyer (1959). Polar lipids were analysed as described by Vaskovsky \& Terekhova (1979). Fatty acid methyl esters were obtained by alkaline methanolysis ( $15 \%$ $\mathrm{NaOH} /$ methanol). The resultant fatty acid methyl esters were extracted with hexane and analysed using a GLC-MS Hewlett Packard model 6890 gas chromatograph equipped with an HP 5 MS $5 \%$ phenyl methyl siloxane capillary column $(30 \mathrm{~m} \times 250 \mu \mathrm{m} \times 0.25 \mu \mathrm{m})$ and connected to a Hewlett Packard model 5973 mass spectrometer. Cellular biomass of strain KMM $3895^{\mathrm{T}}$ for respiratory lipoquinone analysis was obtained from an $\mathrm{MB}$ culture grown at $28^{\circ} \mathrm{C}$. Isoprenoid quinones were extracted using chloroform/ methanol $(2: 1, \mathrm{v} / \mathrm{v})$, purified by preparative TLC on silica gel 60 ADAMANT plates (Fluka) and analysed by HPLC (Agilent 1100 Series) using a reversed-phase column (Hypersil ODS, $5 \mu \mathrm{m} ; 40 \times 250 \mathrm{~mm}$ ). Methanol/2-propanol $(65: 35)$ was used as a mobile phase and quinones were detected at $270 \mathrm{~nm}$. The DNA base composition was determined as described by Marmur \& Doty (1962) and Owen et al. (1969). A 16S rRNA gene sequence of 1506 nucleotides was determined for strain $\mathrm{KMM} 3895^{\mathrm{T}}$ as described by Shida et al. (1997). The sequence obtained was compared with 16S rRNA gene sequences retrieved from the EMBL/GenBank/DDBJ databases by using the FASTA program (Pearson \& Lipman, 1988). Phylogenetic analysis of $16 \mathrm{~S}$ rRNA gene sequences was performed using the software package MEGA 4 (Tamura et al., 2007) after multiple alignment of data by CLUSTAL_X (version 1.83; Thompson et al., 1997). Phylogenetic trees were constructed by the neighbour-joining and maximum-parsimony methods and distances were calculated according to Kimura's two-parameter model. The robustness of phylogenetic trees was estimated by bootstrap analysis of 1000 replicates.

Cultural, physiological and biochemical properties of strain KMM $3895^{\mathrm{T}}$ are listed in Table 1 and in the genus and species descriptions. An analysis of respiratory lipoquinones revealed ubiquinone Q-8 to be the major compound. Polar lipids of strain KMM $3895^{\mathrm{T}}$ included phosphatidylethanolamine, phosphatidylglycerol and diphosphatidylglycerol, an aminophospholipid and an unknown phospholipid (Supplementary Fig. S1, available in IJSEM Online). The predominance of isoprenoid quinone Q-8 has been reported for the related gammaproteobacteria Kangiella koreensis and Kangiella aquimarina (Yoon et al., 2004b) and Microbulbifer hydrolyticus (González et al., 1997; Tang et al., 2008). The presence of phosphatidylethanolamine, phosphatidylglycerol and diphosphatidylglycerol is in accordance with the polar lipids found in some other marine gammaproteobacteria (Romanenko et al., 2003, 2004, 2005). Polar lipids and ubiquinones have not been reported for the phylogenetic neighbours Nitrincola lacisaponensis (Dimitriu et al., 2005), Spongiibacter marinus (Graeber et al., 2008) and Alcanivorax borkumensis (Yakimov et al., 1998; Fernández-Martínez et al., 2003), and polar lipids have not been reported for Kangiella species (Yoon et al., 2004b).

The fatty acid composition of strain KMM $3895^{\mathrm{T}}$ was characterized by the predominance of $\mathrm{C}_{16: 1} \omega 7 c$, iso- $\mathrm{C}_{16: 0}$, iso- $\mathrm{C}_{18: 0}$ and $\mathrm{C}_{18: 1} \omega 7 \mathrm{c}$. The full profile consisted of iso$\mathrm{C}_{14: 0}(4.5 \%), \mathrm{C}_{14: 1} \omega 7(7.5 \%)$, iso- $\mathrm{C}_{15: 1}(3.2 \%), \mathrm{C}_{15: 1}$ $(3.5 \%)$, iso- $\mathrm{C}_{16: 0}(18.6 \%), \mathrm{C}_{16: 1} \omega 7 c(21.1 \%), \mathrm{C}_{16: 0}$ (6.9\%), iso- $\mathrm{C}_{17: 1}(4.7 \%), \mathrm{C}_{17: 1} \omega 5$ (3.0\%), iso- $\mathrm{C}_{18: 1}$ $(2.8 \%)$, iso- $\mathrm{C}_{18: 0}(12.8 \%)$ and $\mathrm{C}_{18: 1} \omega 7 c(11.9 \%)$. Strain KMM $3895^{\mathrm{T}}$ could be distinguished readily from Kangiella species (Yoon et al., 2004b), M. hydrolyticus (González et al., 1997; Tang et al., 2008), Alcanivorax borkumensis (Yakimov et al., 1998; Fernández-Martínez et al., 2003) and S. marinus (Graeber et al., 2008) by the presence of iso$\mathrm{C}_{16: 0}$, iso- $\mathrm{C}_{18: 0}$, iso- $\mathrm{C}_{18: 1}$, iso- $\mathrm{C}_{14: 0}$ and $\mathrm{C}_{14: 1} \omega 7$ and from Kangiella species and S. marinus by the absence of hydroxy branched fatty acids. In contrast to K. koreensis, $K$. aquimarina and $M$. hydrolyticus, the novel isolate KMM $3895^{\mathrm{T}}$ did not contain iso- $\mathrm{C}_{15: 0}$ or iso- $\mathrm{C}_{11: 0}$, but contained $\mathrm{C}_{16: 1} \omega 07 c$ as a major fatty acid. Thus, the fatty acid composition of isolate KMM $3895^{\mathrm{T}}$ can be considered to be unique compared with profiles obtained for related taxa, including S. marinus, $K$. koreensis, $K$. aquimarina, Alcanivorax borkumensis and M. hydrolyticus.

The DNA G + C content of strain KMM $3895^{\mathrm{T}}$ was determined to be $48.1 \mathrm{~mol} \%$. This mean was close to the $\mathrm{G}+\mathrm{C}$ content of $47.4 \mathrm{~mol} \%$ found for N. lacisaponensis, but clearly distinguished the strain from Kangiella species (44 mol\%), S. marinus (69.1 mol\%), M. hydrolyticus (57.7 mol\%) and Alcanivorax borkumensis (53-54 mol\%) (Table 1).

Comparative $16 \mathrm{~S}$ rRNA gene sequence analysis showed that the novel marine sediment isolate $\mathrm{KMM} 3895^{\mathrm{T}}$ was affiliated to the Gammaproteobacteria as a separate line adjacent to the members of the genus Kangiella, $K$. koreensis and $K$. aquimarina (Fig. 1 and Supplementary Fig. S2), and displayed highest sequence similarity of $89.5 \%$ to the type strain of $N$. lacisaponensis and $87-88 \%$ sequence similarity to the members of recognized genera Kangiella, Spongiibacter, Alcanivorax, Saccharophagus and Microbulbifer.

The isolated phylogenetic position of strain KMM $3895^{\mathrm{T}}$ was supported by its unique physiological and biochemical properties. Cells of strain KMM $3895^{\mathrm{T}}$ were Gramnegative, aerobic, non-fermentative, heterotrophic, stenohaline, deep-yellow-pigmented, rod-shaped and nonmotile. Strain KMM $3895^{\mathrm{T}}$ exhibited hydrolytic activities in routine and API ZYM tests as described in Table 1 and the species description. Novel isolate KMM $3895^{\mathrm{T}}$ could be distinguished from its close relatives belonging to the genera Kangiella, Spongiibacter and Nitrincola and from Alcanivorax borkumensis and M. hydrolyticus in minimum and maximum temperatures that support growth, salinity range for growth and metabolic properties (Table 1). 
Table 1. Differential characteristics of strain $\mathrm{KMM} 3895^{\top}$ (Arenicella xantha gen. nov., sp. nov.) and related gammaproteobacteria

Taxa: 1, KMM $3895^{\mathrm{T}}$ (data from the present study); 2, Kangiella koreensis (Yoon et al., 2004b); 3, Kangiella aquimarina (Yoon et al., 2004b); 4, Spongiibacter marinus (Graeber et al., 2008); 5, Alcanivorax borkumensis (Yakimov et al., 1998; Fernández-Martínez et al., 2003); 6, Nitrincola lacisaponensis (Dimitriu et al., 2005); 7, Microbulbifer hydrolyticus (González et al., 1997; Yoon et al., 2004a; Tang et al., 2008). +, Positive; -, negative; s, slow; w, weak; ND, no data available.

\begin{tabular}{|c|c|c|c|c|c|c|c|}
\hline Characteristic & 1 & 2 & 3 & 4 & 5 & 6 & 7 \\
\hline Pigmentation ${ }^{\star}$ & Y & Үв & YB & BG & - & WHBG & $\mathrm{C}$ \\
\hline Motility & - & - & - & + & - & + & - \\
\hline Growth at $4{ }^{\circ} \mathrm{C}$ & - & + & - & - & + & - & - \\
\hline Maximal growth temperature $\left({ }^{\circ} \mathrm{C}\right)$ & 35 & 43 & 48 & 40 & 35 & $\mathrm{ND}$ & 41 \\
\hline $\mathrm{NaCl}$ range for growth $(\%)$ & $1-5$ & $0.5-13$ & $0.5-13$ & $1-7$ & $1-12.5$ & $1-7.5$ & $0.6-6$ \\
\hline Nitrate reduction & - & - & - & $\mathrm{ND}$ & + & + & - \\
\hline Carbohydrate utilization & $\mathrm{w}$ & - & - & + & - & - & + \\
\hline \multicolumn{8}{|l|}{ Hydrolysis of: } \\
\hline Aesculin & + & - & - & ND & - & ND & + \\
\hline Gelatin & + & + & + & ND & - & - & + \\
\hline Starch & + & - & - & $\mathrm{ND}$ & - & - & + \\
\hline Tween 80 & + & + & + & + & + & ND & + \\
\hline Tyrosine & - & + & + & ND & $\mathrm{ND}$ & ND & $\mathrm{ND}$ \\
\hline Casein & s & + & + & ND & ND & ND & + \\
\hline DNA & - & $\mathrm{ND}$ & $\mathrm{ND}$ & $\mathrm{ND}$ & $\mathrm{ND}$ & - & $\mathrm{ND}$ \\
\hline Urea & - & - & - & ND & - & - & ND \\
\hline \multicolumn{8}{|l|}{ Enzyme activity (API ZYM) } \\
\hline Alkaline phosphatase & + & + & + & + & $\mathrm{ND}$ & ND & ND \\
\hline Esterase (C4) & + & + & + & - & $\mathrm{ND}$ & ND & $\mathrm{ND}$ \\
\hline Esterase lipase (C8) & + & + & + & + & $\mathrm{ND}$ & ND & $\mathrm{ND}$ \\
\hline Lipase (C14) & - & - & - & - & $\mathrm{ND}$ & ND & ND \\
\hline Leucine arylamidase & + & + & + & + & $\mathrm{ND}$ & $\mathrm{ND}$ & $\mathrm{ND}$ \\
\hline Valine arylamidase & + & + & + & - & $\mathrm{ND}$ & $\mathrm{ND}$ & $\mathrm{ND}$ \\
\hline Cystine arylamidase & - & - & - & - & $\mathrm{ND}$ & ND & ND \\
\hline Trypsin & + & + & + & - & $\mathrm{ND}$ & $\mathrm{ND}$ & $\mathrm{ND}$ \\
\hline$\alpha$-Chymotrypsin & - & - & - & - & $\mathrm{ND}$ & $\mathrm{ND}$ & ND \\
\hline Acid phosphatase & - & - & + & + & ND & ND & ND \\
\hline Naphthol-AS-BI-phosphohydrolase & - & + & + & + & $\mathrm{ND}$ & ND & $\mathrm{ND}$ \\
\hline$N$-Acetyl- $\beta$-glucosaminidase & - & - & - & + & ND & ND & - \\
\hline$\beta$-Glucosidase & + & - & - & - & ND & ND & ND \\
\hline Major ubiquinone & Q-8 & Q-8 & Q-8 & ND & $\mathrm{ND}$ & ND & Q-8 \\
\hline Main fatty acid(s) $\dagger$ & $\begin{array}{c}\mathrm{C}_{16: 1} \omega 7 c, \mathrm{i}-\mathrm{C}_{16: 0}, \mathrm{i}- \\
\quad \mathrm{C}_{18: 0}, \mathrm{C}_{18: 1} \omega 7 c\end{array}$ & $\mathrm{i}-\mathrm{C}_{15: 0}$ & $\mathrm{i}-\mathrm{C}_{15: 0}$ & $\begin{array}{c}\mathrm{C}_{17: 1} \omega 8, \mathrm{C}_{17: 0} \\
\mathrm{C}_{18: 1} \omega 7\end{array}$ & $\begin{array}{c}\mathrm{C}_{16: 0} \\
\mathrm{C}_{16: 1} \omega 7 c \\
\mathrm{C}_{18: 1} \omega 7 c\end{array}$ & $\mathrm{ND}$ & $\begin{array}{r}\mathrm{i}-\mathrm{C}_{15: 0}, \\
\mathrm{C}_{16: 0}\end{array}$ \\
\hline DNA G + C content $(\mathrm{mol} \%)$ & 48.1 & 44 & 44 & 69.1 & $53-54$ & 47.4 & 57.7 \\
\hline
\end{tabular}

${ }^{*} \mathrm{BG}$, Beige; C, cream; WHBG, whitish beige; Y, yellow; YB, yellowish brown.

$\dagger \mathrm{i}$, iso-branched.

Characteristics that differentiate strain $\mathrm{KMM} 3895^{\mathrm{T}}$ from related gammaproteobacteria are listed in Table 1. On the basis of phenotypic and phylogenetic evidence, it is proposed to classify strain $\mathrm{KMM} 3895^{\mathrm{T}}$ within a novel genus and species, Arenicella xantha gen. nov., sp. nov.

\section{Description of Arenicella xantha gen. nov.}

Arenicella xantha (A.re.ni.cel'la. L. n. arena sand; L. fem. n. cella a chamber, a cell; N.L. fem. n. Arenicella a cell from sand).
Gram-negative, aerobic, oxidase- and catalase-positive, rodshaped bacteria. Chemo-organoheterotrophic. Sodium ions are essential for growth. The predominant isoprenoid quinone is Q-8. Polar lipids include phosphatidylethanolamine, phosphatidylglycerol, diphosphatidylglycerol, an aminophospholipid and an unknown phospholipid. Major fatty acids are $\mathrm{C}_{16: 1} \omega 7 c$, iso- $\mathrm{C}_{16: 0}$, iso- $\mathrm{C}_{18: 0}$ and $\mathrm{C}_{18: 1} \omega 7 c$. The only known strain has been isolated from the marine environment. On the basis of 16S rRNA gene sequence analysis, the genus represents a separate branch within the Gammaproteobacteria, related to the genera Kangiella, 


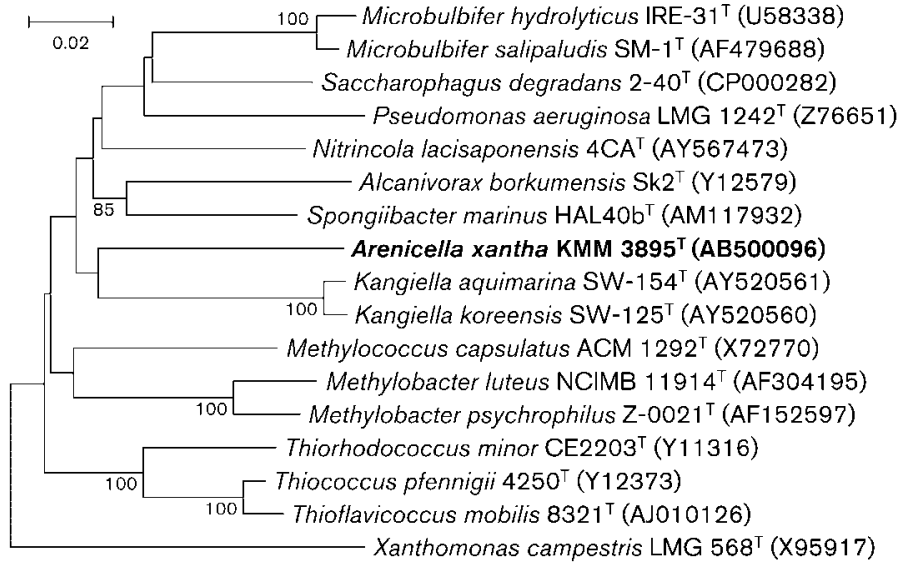

Fig. 1. Neighbour-joining phylogenetic tree based on 16S rRNA gene sequences available from the GenBank/EMBL/DDBJ databases (accession numbers in parentheses) showing the relationship of isolate $\mathrm{KMM} 3895^{\top}$ and related members of the Gammaproteobacteria. Phylogenetic analysis was performed using the software package MEGA 4 (Tamura et al., 2007) after multiple alignment of data by CLUSTAL_X (version 1.83; Thompson et al., 1997). Bootstrap values (greater than $70 \%$ ) based on 1000 replications are given as percentages at branching points. Bar, 0.02 substitutions per nucleotide position.
Spongiibacter, Alcanivorax, Nitrincola and Microbulbifer. The type species is Arenicella xantha.

\section{Description of Arenicella xantha sp. nov.}

Arenicella xantha (xan'tha. N.L. fem. adj. xantha from Gr. adj. xanthos yellow-coloured).

In addition to properties given in the genus description, the species is characterized as follows. Cells are $0.5-0.6 \mu \mathrm{m}$ in diameter and 3.0-4.0 $\mu \mathrm{m}$ long. Non-motile. Produces deep-yellow-pigmented, smooth, shiny colonies with regular edges, $2-3 \mathrm{~mm}$ in diameter, on MA. Requires $\mathrm{NaCl}$ for growth; growth occurs at $1-5 \%(\mathrm{w} / \mathrm{v}) \mathrm{NaCl}$ and is optimal with $2-3 \%$. Grows well in/on peptone medium containing $\mathrm{NaCl}$ alone without the addition of any of the components of sea salts $\left(\mathrm{MgCl}_{2}, \mathrm{KCl}, \mathrm{CaCl}_{2}, \mathrm{NaNO}_{3}\right.$, $\mathrm{K}_{2} \mathrm{HPO}_{4}, \mathrm{KCl}, \mathrm{NaSO}_{4}, \mathrm{NaHCO}_{3}, \mathrm{NaF}$ and $\mathrm{FeSO}_{4}$ ). No growth on basal medium supplemented with $0.1 \%$ glycerol, $0.1 \%$ potassium acetate or $0.1 \%$ potassium succinate or on basal medium when the $\mathrm{Na}^{+}$salts are replaced by equimolar amounts of $\mathrm{K}^{+}$salts. Shows weak growth on D-glucose, melibiose, L-arabinose, D-ribose, Dxylose and L-alanine and no growth on maltose, sucrose, Dgalactose, $\mathrm{N}$-acetylglucosamine, lactose, raffinose, L-rhamnose, D-mannose, cellobiose, glycerol, acetate, glutamic acid, DL-methionine, D-mannitol, citrate, L-asparagine, Larginine, L-phenylalanine, L-valine, L-lysine, L-leucine and L-histidine. Psychrotolerant; the temperature range for growth is $5-35{ }^{\circ} \mathrm{C}$, with optimum growth at $25-28{ }^{\circ} \mathrm{C}$. No growth is observed at $4{ }^{\circ} \mathrm{C}$ or above $35^{\circ} \mathrm{C}$. The $\mathrm{pH}$ range for growth is 6.0-11.0 with an optimum at $\mathrm{pH}$ 8.5-9.5. Negative for $\mathrm{H}_{2} \mathrm{~S}$ production. Positive for hydrolysis of gelatin, starch and Tweens 20, 40 and 80. Casein is hydrolysed in 3-5 days. Does not degrade CM-cellulose, agar, chitin or DNA. On L-tyrosine-containing medium, does not produce melanin-like pigments and/or clearance zones. No acid production is observed from D-glucose, maltose, sucrose, lactose, D-galactose, D-mannose, cellobiose, D-xylose, L-arabinose, L-rhamnose, D-sorbitol or Dmannitol. According to API $20 \mathrm{NE}$ tests, positive for aesculin hydrolysis, gelatin hydrolysis and the PNPG test ( $\beta$-glucosidase) and negative for nitrate reduction, indole production, D-glucose acidification under anaerobic conditions, production of arginine dihydrolase and urease and assimilation of D-glucose, L-arabinose, D-mannose, Dmannitol, $\mathrm{N}$-acetylglucosamine, maltose, D-gluconate, caprate, adipate, L-malate, citrate and phenylacetate. According to API $20 \mathrm{E}$ tests, positive for gelatin hydrolysis and the PNPG test and negative for arginine dihydrolase, lysine decarboxylase, ornithine decarboxylase, citrate utilization, $\mathrm{H}_{2} \mathrm{~S}$ production under anaerobic conditions, urease, tryptophan deaminase, indole production, acetoin production (Voges-Proskauer reaction) and oxidation or fermentation of D-glucose, D-mannitol, inositol, D-sorbitol, L-rhamnose, sucrose, melibiose, amygdalin and L-arabinose. According to API ZYM tests, positive for alkaline phosphatase, esterase (C4), esterase lipase (C8), leucine arylamidase, valine arylamidase, trypsin and $\beta$-glucosidase and negative for lipase (C14), cystine arylamidase, $\alpha$ chymotrypsin, acid phosphatase, naphthol-AS-BI-phosphohydrolase, $N$-acetyl- $\beta$-glucosaminidase, $\alpha$-galactosidase, $\beta$-galactosidase, $\alpha$-glucosidase, $\beta$-glucuronidase, $\alpha$ mannosidase and $\alpha$-fucosidase. The fatty acid profile includes (in decreasing order of abundance) $\mathrm{C}_{16: 1} \omega 7 c$, iso- $\mathrm{C}_{16: 0}$, iso- $\mathrm{C}_{18: 0}, \mathrm{C}_{18: 1} \omega 7 c, \mathrm{C}_{14: 1} \omega 7, \mathrm{C}_{16: 0}$, iso- $\mathrm{C}_{17: 1}$, iso- $\mathrm{C}_{14: 0}, \mathrm{C}_{15: 1}$, iso- $\mathrm{C}_{15: 1}, \mathrm{C}_{17: 1} \omega 5$ and iso- $\mathrm{C}_{18: 1}$. Susceptible to (content per disc) ampicillin $(10 \mu \mathrm{g})$, benzylpenicillin $(10 \mathrm{U})$, carbenicillin $(100 \mu \mathrm{g})$, gentamicin $(10 \mu \mathrm{g})$, oleandomycin $(15 \mu \mathrm{g})$, rifampicin $(5 \mu \mathrm{g})$, streptomycin $(30 \mu \mathrm{g})$, kanamycin $(30 \mu \mathrm{g})$, nalidixic acid $(30 \mu \mathrm{g})$, neomycin $(30 \mu \mathrm{g})$, ofloxacin $(5 \mu \mathrm{g})$, erythromycin $(15 \mu \mathrm{g})$, cephazolin $(30 \mu \mathrm{g})$, cephalexin $(30 \mu \mathrm{g})$ and chloramphenicol $(30 \mu \mathrm{g})$ and resistant to vancomycin $(30 \mu \mathrm{g})$, lincomycin $(15 \mu \mathrm{g})$, oxacillin $(10 \mu \mathrm{g})$, polymyxin $(300 \mathrm{U})$ and tetracycline $(30 \mu \mathrm{g})$. The DNA G $+\mathrm{C}$ content of the type strain is $48.1 \mathrm{~mol} \%$ (thermal denaturation method).

The type strain, KMM $3895^{\mathrm{T}}\left(=\mathrm{NRIC} 0759^{\mathrm{T}}=\mathrm{JCM}\right.$ $\left.16153^{\mathrm{T}}\right)$, was isolated from a sandy sediment sample collected offshore from the Sea of Japan, Russia. 


\section{Acknowledgements}

This study was supported by State Contract 02.518.11.7169 from the Federal Agency for Science and Innovations of the Russian Federation, by a grant from Presidium Far-Eastern Branch of Russian Academy of Sciences 09-III-A-06_227 and by a grant from Presidium of RAS 'Molecular and Cell Biology'.

\section{References}

Baumann, P. \& Baumann, L. (1981). The marine Gram-negative eubacteria: genera Photobacterium, Beneckea, Alteromonas, Pseudomonas and Alcaligenes. In The Prokaryotes, vol. 1, pp. 13021330. Edited by M. P. Starr, H. Stolp, H. G. Trüper, A. Balows \& H. Schlegel. Berlin: Springer.

Bligh, E. G. \& Dyer, W. J. (1959). A rapid method of total lipid extraction and purification. Can J Biochem Physiol 37, 911-917.

Dimitriu, P. A., Shukla, S. K., Conradt, J., Márquez, M. C., Ventosa, A., Maglia, A., Peyton, B. M., Pinkart, H. C. \& Mormile, M. R. (2005). Nitrincola lacisaponensis gen. nov., sp. nov., a novel alkaliphilic bacterium isolated from an alkaline, saline lake. Int J Syst Evol Microbiol 55, 2273-2278.

Fernández-Martínez, J., Pujalte, M. J., García-Martínez, J., Mata, M., Garay, E. \& Rodríguez-Valera, F. (2003). Description of Alcanivorax venustensis sp. nov. and reclassification of Fundibacter jadensis DSM $12178^{\mathrm{T}}$ (Bruns and Berthe-Corti 1999) as Alcanivorax jadensis comb. nov., members of the emended genus Alcanivorax. Int J Syst Evol Microbiol 53, 331-338.

Gerhardt, P., Murray, R. G. E., Wood, W. A. \& Krieg, N. R. (editors) (1994). Methods for General and Molecular Bacteriology. Washington, DC: American Society for Microbiology.

González, J. M., Mayer, F., Moran, A., Hodson, R. E. \& Whitman, W. B. (1997). Microbulbifer hydrolyticus gen. nov., sp. nov., and Marinobacterium georgiense gen. nov., sp. nov., two marine bacteria from a lignin-rich pulp mill waste enrichment community. Int J Syst Bacteriol 47, 369-376.

Graeber, I., Kaesler, I., Borchert, M. S., Dieckmann, R., Pape, T., Lurz, R., Nielsen, P., Von Döhren, H., Michaelis, W. \& Szewzyk, U. (2008). Spongiibacter marinus gen. nov., sp. nov., a halophilic marine bacterium isolated from the boreal sponge Haliclona sp. 1. Int J Syst Evol Microbiol 58, 585-590.

Leifson, E. (1963). Determination of carbohydrate metabolism of marine bacteria. J Bacteriol 85, 1183-1184.

Marmur, J. \& Doty, P. (1962). Determination of the base composition of deoxyribonucleic acid from its thermal denaturation temperature. J Mol Biol 5, 109-118.

Owen, R. J., Hill, L. R. \& Lapage, S. P. (1969). Determination of DNA base composition from melting profiles in dilute buffers. Biopolymers 7, 503-516.
Pearson, W. R. \& Lipman, D. J. (1988). Improved tools for biological sequence comparison. Proc Natl Acad Sci U S A 85, 2444-2448.

Romanenko, L. A., Schumann, P., Zhukova, N. V., Rohde, M., Mikhailov, V. V. \& Stackebrandt, E. (2003). Oceanisphaera litoralis gen. nov., sp. nov., a novel halophilic bacterium from marine bottom sediments. Int J Syst Evol Microbiol 53, 1885-1888.

Romanenko, L. A., Schumann, P., Rohde, M., Mikhailov, V. V. \& Stackebrandt, E. (2004). Reinekea marinisedimentorum gen. nov., sp. nov., a novel gammaproteobacterium from marine coastal sediments. Int J Syst Evol Microbiol 54, 669-673.

Romanenko, L. A., Uchino, M., Falsen, E., Frolova, G. M., Zhukova, N. V. \& Mikhailov, V. V. (2005). Pseudomonas pachastrellae sp. nov. isolated from a marine sponge. Int J Syst Evol Microbiol 55, 919-924.

Shida, O., Takagi, H., Kadowaki, K., Nakamura, L. K. \& Komagata, K. (1997). Transfer of Bacillus alginolyticus, Bacillus chondroitinus, Bacillus curdlanolyticus, Bacillus glucanolyticus, Bacillus kobensis, and Bacillus thiaminolyticus to the genus Paenibacillus and emended description of the genus Paenibacillus. Int J Syst Bacteriol 47, 289298.

Smibert, R. M. \& Krieg, N. R. (1994). Phenotypic characterization. In Methods for General and Molecular Bacteriology, pp. 607-654. Edited by P. Gerhardt, R. G. E. Murray, W. A. Wood \& N. R. Krieg. Washington, DC: American Society for Microbiology.

Tamura, K., Dudley, J., Nei, M. \& Kumar, S. (2007). MEGA 4: molecular evolutionary genetics analysis (MEGA) software version 4.0. Mol Biol Evol 24, 1596-1599.

Tang, S.-K., Wang, Y., Cai, M., Lou, K., Mao, P. H., Jin, X., Jiang, C.-L., Xu, L.-H. \& Li, W.-J. (2008). Microbulbifer halophilus sp. nov., a moderately halophilic bacterium from north-west China. Int J Syst Evol Microbiol 58, 2036-2040.

Thompson, J. D., Gibson, T. J., Plewniak, F., Jeanmougin, F. \& Higgins, D. G. (1997). The CLUSTAL_X windows interface: flexible strategies for multiple sequence alignment aided by quality analysis tools. Nucleic Acids Res 25, 4876-4882.

Vaskovsky, V. E. \& Terekhova, T. A. (1979). HPTLC of phospholipid mixtures containing phosphatidylglycerol. J High Resolut Chromatogr 2, 671-672.

Yakimov, M. M., Golyshin, P. N., Lang, S., Moore, E. R. B., Abraham, W.-R., Lünsdorf, H. \& Timmis, K. N. (1998). Alcanivorax borkumensis gen. nov., sp. nov., a new, hydrocarbon-degrading and surfactantproducing marine bacterium. Int J Syst Bacteriol 48, 339-348.

Yoon, J.-H., Kim, I.-G., Oh, T.-K. \& Park, Y.-H. (2004a). Microbulbifer maritimus sp. nov., isolated from an intertidal sediment from the Yellow Sea, Korea. Int J Syst Evol Microbiol 54, 1111-1116.

Yoon, J.-H., Oh, T.-K. \& Park, Y.-H. (2004b). Kangiella koreensis gen. nov., sp. nov. and Kangiella aquimarina sp. nov., isolated from a tidal flat of the Yellow Sea in Korea. Int J Syst Evol Microbiol 54, 18291835 . 